\title{
THE ROLE OF A WATER CANAL AND SECONDARY FOREST FOR MIGRANTS
}

\author{
Beáta Schupkégel ${ }^{1}$, László Bozón ${ }^{*}$, Csaba Tölgyesi ${ }^{3}$
}

\begin{abstract}
Schupkégel B., Bozó L., Tölgyesi C. 2020. The role of a water canal and secondary forest for migrants. Ring 42: 3-13.

Forests have an important role during migration. They act as ecological corridors and provide resting and feeding places for birds. In our study, we sought to determine whether migratory birds prefer secondary forest or canal vegetation during migration. The study was carried out in Southeast Hungary, in an oleaster forest and in a canal. We used 12 mist nets and the ringing method. The study period lasted from August to October 2016-2018, covering approximately the entire migration period. According to our results, the canal has a significant effect on the species assemblage, as it functions as a migration corridor during migration, most likely not only for diurnal migrants, but for nocturnal migrants as well. Our results showed that the presence of both woody and berry plants had some influence on the species composition. Interestingly, the presence of berries had a positive effect on the presence of insectivorous birds.
\end{abstract}

B. Schupkégel ${ }^{1}$, Department of Ecology, University of Szeged, 6726 Szeged, Közép fasor 52, Hungary, email: betti302@freemail.hu; L. Bozó ${ }^{* *}$, Department of Systematic Zoology and Ecology, Eötvös Loránd University, 1117 Budapest, Pázmány Péter sétány 1/c, Hungary (corresponding author); C. Tölgyesi ${ }^{3}$, Department of Ecology, University of Szeged, 6726 Szeged, Közép fasor 52, Hungary

Keywords: passerines, autumn migration, agriculture, Elaeagnus angustifolia, Carpathian Basin

\section{INTRODUCTION}

Agricultural habitats (forest belts, canals, and lines of trees) are often food-rich areas, so they can provide an excellent living space for various species (Eversham and Telfer 1994, Gallé et al. 1995). Many studies have focused on birds of forest belts on agricultural lands (Gál 1968, Herrmann and Plakolm 1991, Legány 1991, Kromp 1998, Szarvas 2010) and tangentially on the role of lines of trees and canals (Bozó et al. 2017), but most of these studies used data only from the breeding period. They showed that the best-known and most common songbirds occurred in these habitats (Legány 1991, Szarvas 2010). Birds prefer to use heterogeneous vegetation, where 
they are more likely to find suitable resting or nesting places than in a homogeneous area (Benke et al. 2010). In addition to heterogeneity, the quality of vegetation is also an important factor, as the number of bird species occurring in such habitats depends on the extent and age of the vegetation (Szarvas 2010). Other factors may include the traffic on the roads along the line of trees and the agricultural technologies used, such as chemicals or machinery in the fields (Legány 1991, Gál and Marosán 2003, Szarvas 2010).

Forest belts and canals also play a crucial role in the agri-environment as green corridors (Forman and Godron 1986). These corridors, also known as ecological corridors, are linear areas that differ from their surroundings (Forman and Godron 1986). By facilitating the migration of animals and the spread of plant propagules, they provide a connection between fragmented areas (Barna 1994, Altieri 1999, Baudry et al. 2000, Fülöp and Szilvácsku 2000, Marton and Csikós 2004). Since research on songbird migration is primarily associated with ringing stations that operate in often protected natural habitats, there is almost no available information about such secondary habitats. According to Bozó et al. (2017), these habitats play a crucial role in the migration not only of common species, but also of rare and very interesting species of passerines.

In this study, we examined whether the species migrating through the area preferred the forest or used only the lines of trees along the canal, which provide much less food. We also studied the species composition in these two habitats and the effect of woody plants and berries on migrating birds.

\section{MATERIAL AND METHODS}

The research was carried out in south-eastern Hungary, within the administrative boundary of Kevermes, at the site of a former pheasant station (46 $\left.26^{\prime} \mathrm{N} 21^{\circ} 12^{\prime} \mathrm{E}\right)$, which is a 7 ha oleaster (Elaeagnus angustifolia) forest (Figure 1). The research site is in the northern part of the forest within an area of about 0.5 ha. The average height of the forest is 3.5-4 m. In addition to the dominant oleaster, some higher elm (Ulmus sp.), black locust (Robinia pseudoacacia) and European wild pear (Pyrus pyraster) can also be found. The shrub layer consists mainly of black elderberry (Sambucus nigra) and sloe (Prunus spinosa), while dewberries (Rubus caesius) are the most common plant species in the lower levels. Vegetation is denser at the edge of the forest, with spots of reeds and weeds next to the dominant sloe and black elderberry. Behind the forest there is a drainage canal (Tulkán Canal) with SE-NW orientation. Willows (Salix sp.), young walnuts (Juglans regia) and poplar trees (Populus sp.) grow on the shore, and the canal bed is covered with dense reeds. The average height of the plants in the canal was almost the same as in the forest $(3-3.5 \mathrm{~m})$. Therefore, the probability of capture of birds was essentially the same in both habitats. The canal is shallow with periodic water cover in the deeper parts. In 2016, only a small amount of water appeared in the second half of October, while in 2017 and 2018 the river bed remained dry throughout the study period. The forest and the canal border on agricultural land. 


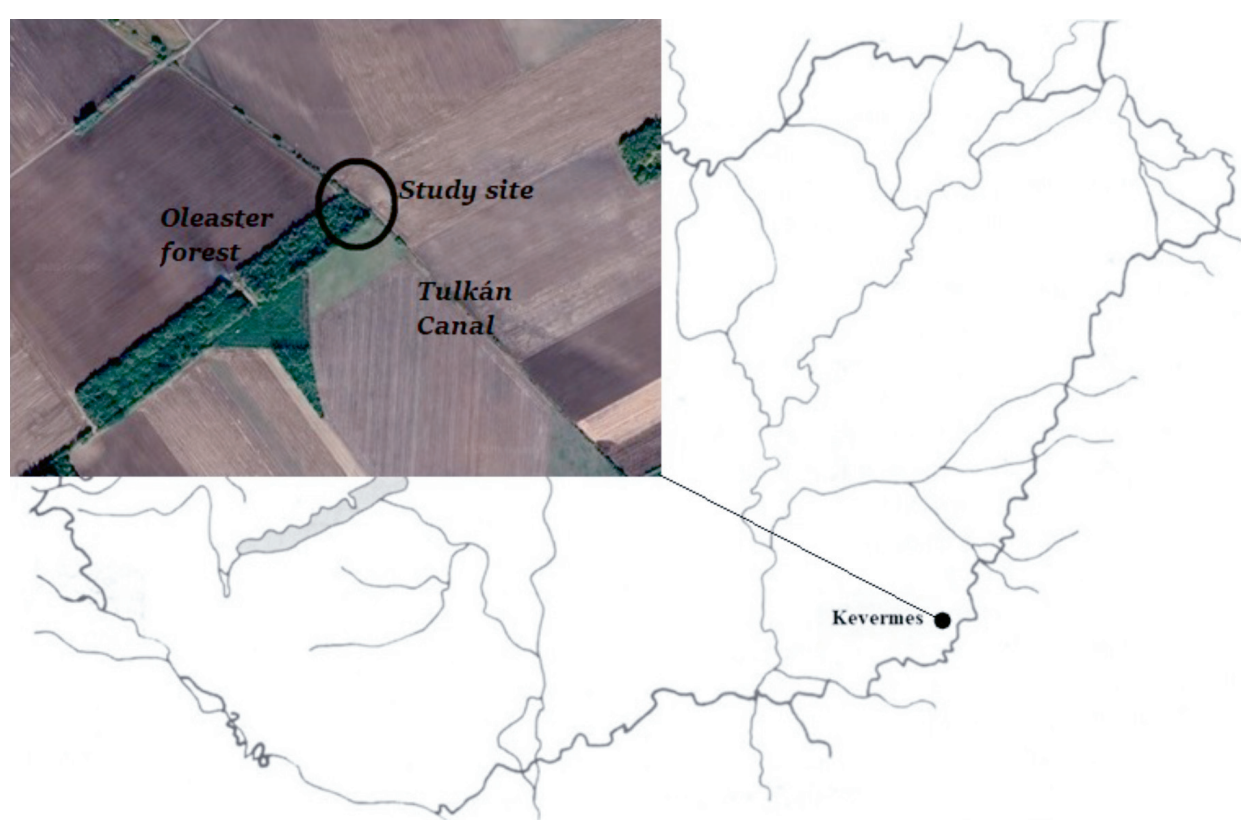

Fig. 1. Map of the study site and its location within Hungary

In all three years of the study (2016-2018), the method of catching and ringing birds was used for data collection; each bird was ringed after it was caught. We also collected various biometric data for the individuals (length of wing, tail, P8, bill, and tarsus; fat score, muscle score and weight), determined their age and sex according to Svensson (1992), and finally released them. The work was conducted between 8 August and 27 October in 2016, between 3 August and 27 October in 2017, and between 3 August and 23 October in 2018. One day means eight hours, i.e. eight controls (four in the morning and four in the afternoon). In each of the three years, 12 mist nets were deployed. Of these, nine nets were placed in the oleaster forest and three along the canal.

In September 2017, we mapped the vegetation around the nets. The average height of the vegetation was measured on the right and left sides of each net at three and six meters, three points per line. The dominant species of plants were also recorded.

A mixed linear model was used to investigate the impact of habitat type (forest or line of trees along the canal) on the number of species and individuals. Both habitats and species composition were analysed by PerMANOVA analysis. Ordination using non-metric multidimensional scaling provided a visual illustration of the typical species composition of the habitats. Bray-Curtis distance was used as a distance function, and two dimensions were given to produce the point distribution. The distance between the points on the chart is proportional to the difference between the values. The Mantel test was used to correlate the set of species with cover by woody and berry plants, while the influence of berry plants on the total abundance of birds was 
investigated using a linear model. The species were divided into two groups for the analyses: frugivorous and insectivorous (Table 2). Finally, we used indicator species analysis to examine whether there were species that were significantly related to a single habitat type.

For the statistical analyses we used R 3.4.2 (R Development Core Team 2018).

\section{RESULTS}

The occurrence of typical food plants and reeds around the nets is presented in Table 1. The largest proportions of woody trees were found around nets nos. 7 and 9 . There was no woody cover around net CS2. Berry cover was the highest around net no. 2, while there was no berry cover around nets $7,8, \operatorname{CS} 2$ and CS3. The reed cover was largest around net CS2. During the three years of the study we captured 4517 individuals of 52 species (Table 2).

Table 1

The occurrence of typical food plants and reeds around nets.

A + sign indicates the presence of food plants and reeds, and a sign indicates their absence around the nets.

\begin{tabular}{|l|c|c|c|c|c|c|c|c|c|c|c|c|}
\hline \multirow{2}{*}{\multicolumn{1}{|c|}{ Food plant }} & \multicolumn{1}{|c|}{ Forest nets } \\
\cline { 2 - 22 } & 1 & 2 & 3 & 4 & 5 & 6 & 7 & 8 & 9 & 1 & 2 & 3 \\
\hline Sambucus nigra & + & + & + & + & - & - & - & - & + & - & - & - \\
\hline Prunus spinosa & + & - & - & + & + & + & - & - & + & - & - & - \\
\hline Rosa canina & + & - & - & - & + & - & - & - & - & + & - & - \\
\hline Phytolacca americana & + & - & - & - & - & - & - & - & + & - & - & - \\
\hline Carduus & + & - & - & + & - & - & - & - & - & - & + & - \\
\hline Rubus caesius & + & + & + & + & + & + & + & + & + & - & - & - \\
\hline Phragmites australis & + & - & - & - & - & - & - & - & - & + & + & + \\
\hline
\end{tabular}

\section{Impact of habitat types on avian species composition and abundance}

The mixed linear modelling showed that the species richness of birds captured in the nets located by the canal was higher than in the nets in the forest. The higher value is not random but due to the presence of the canal $(z=-2.86, p=0.04)$. Figure 2 shows the species composition in the nets of each habitat type. The difference from the average in the forest was 6.11, while the difference from the average in the canal was 3.14. The minimum number of species was 5 and the maximum number was 29 in the forest, while the corresponding values in the canal were 23 and 33 . It is worth noting that in the case of nets located by the canal, the difference was not so large and the deviation from the mean was not significant. In the case of the forest, the difference from the average was significant. In one net, the number of captured species differed by more than 10 species from the mean. Greater differences in species composition were noted in the case of nets in the forest. 


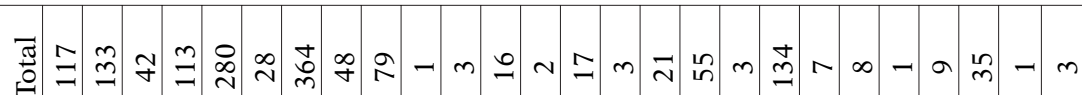

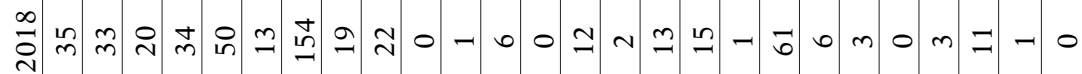

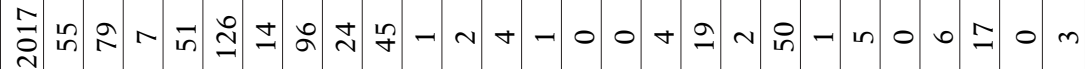

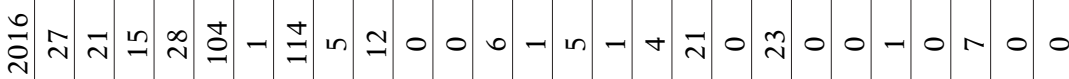

离

薂

我

चี

to

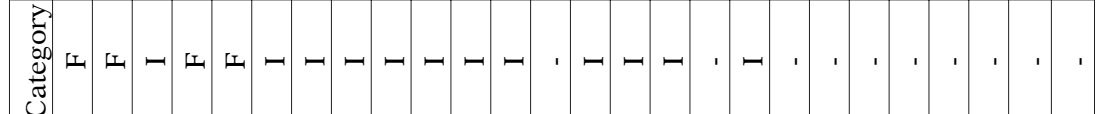

0

3
$\frac{3}{3}$
$\frac{3}{3}$
3
3
3

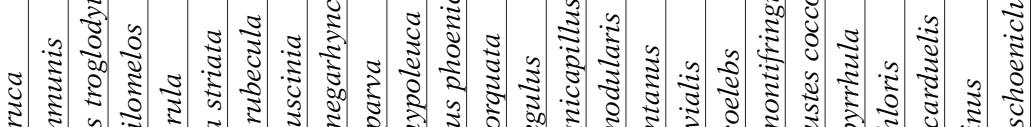

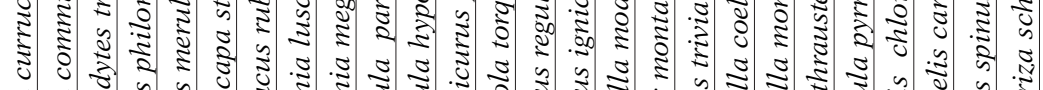

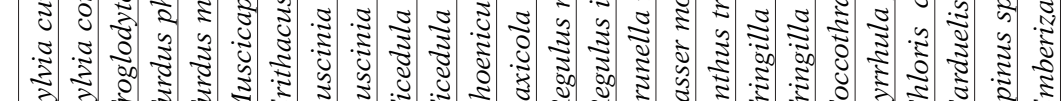

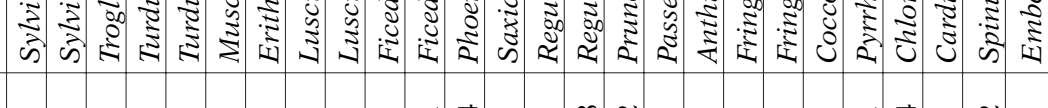

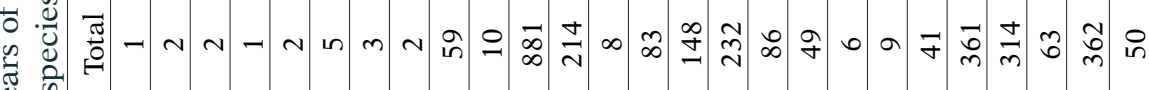
क्ष के

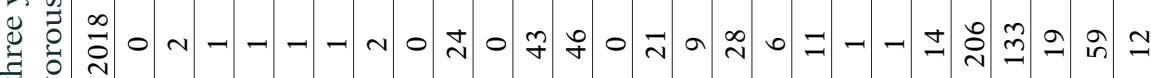

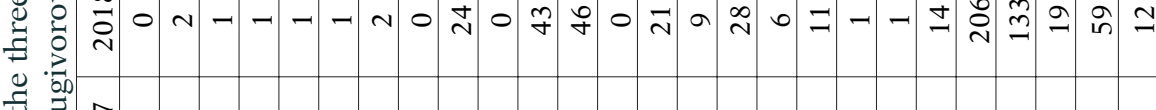

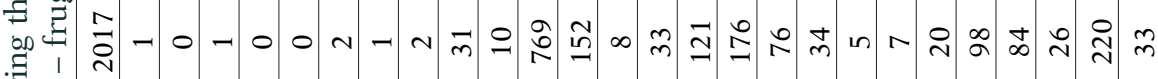

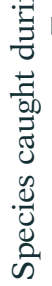

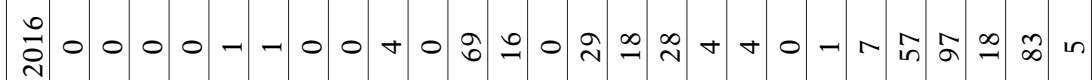

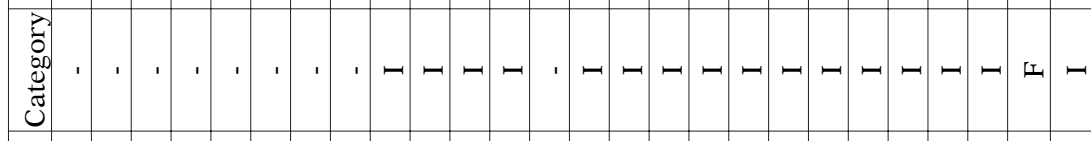

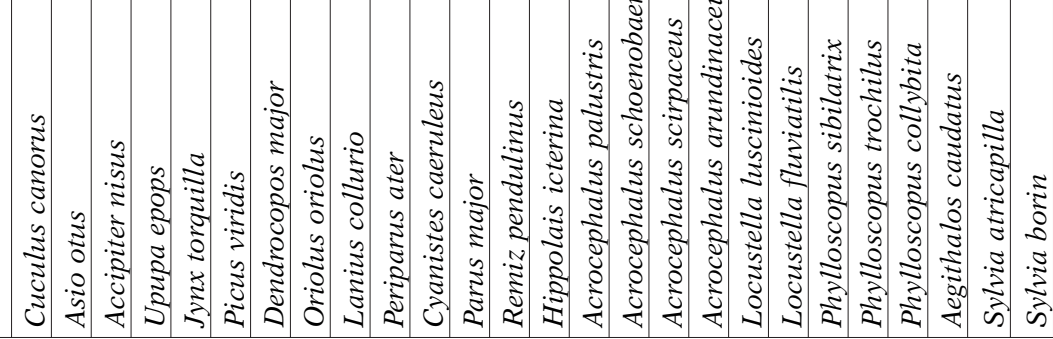




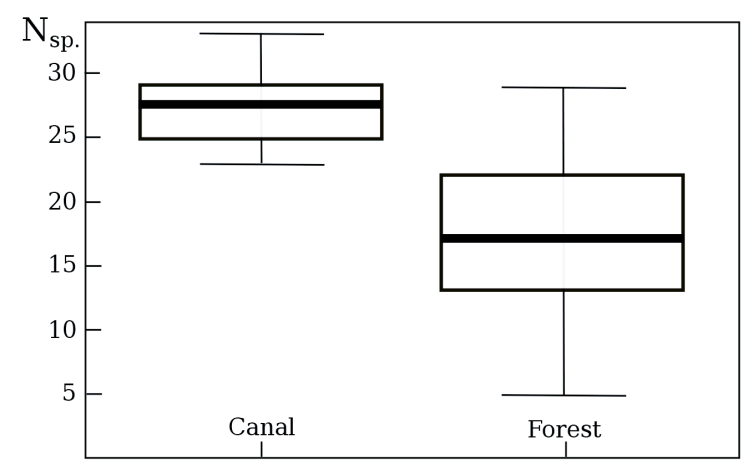

Habitat type

Fig. 2. Number of species $\left(N_{s p}\right.$. $)$ captured by the nets in different habitat types

In terms of the number of individuals, we also found that significantly more individuals were captured at the canal than in the forest $(z=2.19, p=0.03$; Figure 3).

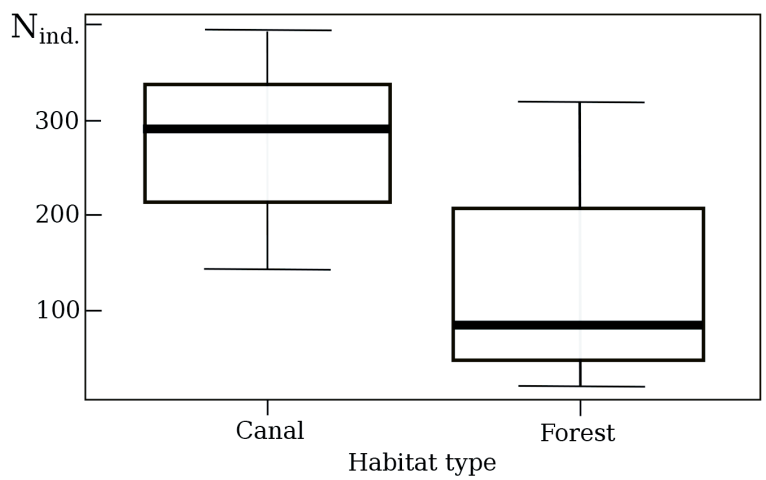

Fig. 3. Number of individuals $\left(N_{\text {ind }}\right.$ ) caught in different habitat types

\section{Species composition test}

The PerMANOVA test showed that the canal had a significant effect on the species assemblage $(F=4.95, p=0.003)$, with $13.8 \%$ of the species diversity explained by habitat type (nets placed in the forest or at the canal). The same result was confirmed by the ordination analysis (stress factor: 0.14 ).

\section{The effect of woody plants and berry cover on species composition}

The Mantel test showed that the species composition was affected by the presence of woody plants $(r=0.33, p=0.001)$ and berries $(r=0.14, p=0.021)$. We used a linear model to examine the effect of berry plants on the number of frugivorous species. According to the results of the model, the presence of berry plants had no effect on the occurrence of frugivorous species $\left(t=0.15, p=0.88, R^{2}=0.01\right)$. 
We also tested the possibility that berry plants, while not influencing the number of frugivorous species, might have an effect on insectivorous species. The results showed that the presence of berry plants and their abundance around the net affected the number of insectivorous species $(t=2.68, p=0.01)$. This model explained $19.3 \%$ of the data variability.

\section{Indicator species analysis}

The indicator species analysis showed that all species present in the forest also occurred at the canal; however, there were 15 species that were significantly associated with the canal: Thrush Nightingale Luscinia luscinia, European Stonechat Saxicola torquata, Common Whitethroat Sylvia communis, Icterine Warbler Hippolais icterina, Savi's Warbler Locustella luscinioides, River Warbler L. fluviatilis, Sedge Warbler Acrocephalus schoenobaenus, Eurasian Reed Warbler A. scirpaceus, Marsh Warbler A. palustris, Great Reed Warbler A. arundinaceus, Eurasian Penduline Tit Remiz pendulinus, Red-backed Shrike Lanius collurio, Eurasian Tree Sparrow Passer montanus, European Greenfinch Chloris chloris and Common Reed Bunting Emberiza schoeniclus. These were recognized as indicator species.

\section{DISCUSSION}

Based on the results of the mixed linear model and the PerMANOVA test, the presence of the canal had a significant effect on the species composition. Canals may be interpreted as migration corridors (Barna 1994, Altieri 1999, Baudry et al. 2000, Fülöp and Szilvácsku 2000, Marton and Csikós 2004), as birds follow them during migration (Bozó et al. 2017). Our visual observations of various diurnal migrant species, such as Blue Tit Cyanistes caeruleus, clearly show that birds follow the canal when migrating. Because it is very rare to find natural habitats providing suitable resting places for birds in an artificial agricultural landscape, the canal may also play an important role in the case of nocturnal migrating species. This may be supported by the fact that significantly fewer individuals were captured in the forest nets, although there are far more nutrients in the forest even in the early morning and late afternoon, when the birds finish or begin their migration. This can probably be explained by the assumption that most of the individuals move along the narrow linear strip of the canal but do not use the area as a stopover site. Individuals that were trapped in the forest may have been able to feed there, but they do not use it intensively. Suitable stopover sites, where resting and re-fuelling needs may be met, are critical for migrant survival and the long-term sustainability of migratory bird populations (for review see Faaborg et al. 2010). Thus we can assume that our study site is not an important stopover site for these birds. However, two thrush nightingales have been recaptured in different years (Bozó 2018). The species is well known to have very high stopover site fidelity (Csörgő and Kováts 2009), so we cannot rule out that the study site is an important stopover site for this species. It should be noted that this is the only species with long-term recaptures, so it can be considered an exception. 
Analysis of the effect of woody plants and berry cover on the number of species showed that the presence of both groups influences the species composition. Woody stems, oleasters, black locusts, elms, wild pears and walnuts, among others, were found in the vicinity of the nets. Oleaster is an alien invasive species that can rapidly populate an area by crowding out native species, and only low-diversity communities develop in oleaster forests (Botta-Dukát 2006). This is because the leaves have few natural pests due to their tannin content (Bartha and Csiszár 2012), which is an advantage over native species. However, it is less attractive to insectivorous birds. Nevertheless, after their preferred elderberries are gone, some species, e.g. thrushes, rely on the oleaster crop (Bozó 2019), which is rich in vitamins and oils but low in sugar (Botta-Dukát 2006). We caught low numbers of each of these species in the nets in the forest, suggesting that most migratory species avoided the closed oleaster forest. Thus, oleaster trees (due to their negative and positive properties) and other woody plants around the nets (black locust and wild pear, which are also important food plants) had a combined effect on the species composition of the nets in the forest. It would be interesting to investigate the effect of oleaster trees on the wintering bird populations in the area, as Bozó (2019) found that for Fieldfares Turdus pilaris this was the most important food in winter. Perhaps over time, in late autumn and in winter, the oleaster forest had a much more important role not only for fieldfares but for other small passerines as well.

In addition to woody plant cover, species caught in the forest were also affected by the presence of berries. Interestingly, however, there was no correlation between the number of frugivorous species and cover by berry plants, but the presence of insectivorous species was positively influenced by coverage by berries. This may be because birds did not feed on the berries but on insects present on rotting berries. Many insectivorous species, such as the Sedge Warbler or the Eurasian Blackcap Sylvia atricapilla, prefer to eat elderberry before autumn migration, but the most common species (e.g. leaf warblers and tits) do not change their diet during migration and feed on insects (Csörgő et al. 2009). For late migrants, such as the Eurasian Robin Erithacus rubecula and Common Blackbird Turdus merula, these berries are not available, as they have dried up due to the frequent dry weather. Some species prefer to prey on woody areas and bushes during migration, such as the Goldcrest Regulus regulus, the Common Firecrest $R$. ignicapilla, the Eurasian Wren Troglodytes troglodytes and the European Robin, but these species are late migrants in the area and feed mostly on insects.

As expected, the results of the indicator species analysis showed that the majority of the indicator species occurred in the canal. The presence of the Sedge Warbler, Eurasian Reed Warbler, Marsh Warbler, Savi's Warbler, Great Reed Warbler, Eurasian Penduline Tit and Common Reed Bunting is clearly due to the dominant vegetation (reed beds and willows) in the canal, where these species typically can be found during migration. The presence of the Thrush Nightingale, Icterine Warbler and River Warbler and their significant relationship with the canal may highlight the decisive role of the canal in migration, as these species are common migrants in Hungary (Hadarics and Zalai 2008, Csörgő et al. 2009), but none of them breeds in our region (Bozó 2017, 2018). This is also confirmed by the number of yearly captures of 
these species, as during the three years of the study we were able to catch 10-15\% of all individuals captured in Hungary (Karcza 2019). The Red-backed Shrike, Common Whitethroat and European Stonechat are declining breeders in agricultural lands, and all of them prefer to nest near canals in bushes and weeds. Our indicator species analyses showed that these species essentially used the same habitat during migration. In the case of the Eurasian Tree Sparrow and European Greenfinch, this connection was probably not due to the quality of the habitat but to its physical location. According to our field observations, both species feed in large numbers on the surrounding stubble and often fly over the canal from one place to another. They also fly into the nets during such random movements.

Summing up, canals are likely to play an important role in migration not only for diurnal species but for nocturnal migratory species as well. However, birds also use the secondary forests during migration as a stopover site. Therefore, the importance of protecting forests, lines of trees, canals and vegetation along the canals cannot be stressed enough. For many species, forest strips and drainage canals are the only habitats that can be used in such an agri-environment. Due to agricultural land management, land use and canal cleaning programmes, many bird species associated with secondary forests, lines of trees, and reed beds are disappearing. The current form of canal management causes enormous problems, and in many cases is redundant. Protecting these habitats and reducing their destruction must be a priority in the future.

\section{ACKNOWLEDGEMENTS}

The authors are grateful to the volunteers of the bird ringing camp for their help with the field work. The field work was supported by the Hungarian Young National Talents Scholarship (grant number: NTP-NFTÖ-18-B-0204). The authors are grateful to Nikolett Olajos for help with the English presentation of the text.

\section{REFERENCES}

Altieri M.A. 1999. The ecological role of biodiversity in agroecosystems. Agr. Ecosyst. Environ 74: 19-31.

Barna T. (ed) 1994. Erdőmüveléstan. Egyetemi tankönyv. Erdészeti és Faipari Egyetem Erdőmérnöki Kar, Sopron. (In Hungarian).

Bartha D., Csiszár Á. 2012. Keskenylevelü ezüstfa (Elaeagnus angustifolia). [Oleaster (Elaeagnus angustifolia)]. In: Csiszár Á., (Ed). Inváziós növényfajok Magyarországon. [Invasive plant species in Hungary]. Nyugat-magyarországi Egyetemi Kiadó, Sopron, pp. 115-120. (In Hungarian).

Baudry J., Bunce R.G.H., Burel F. 2000. Hedgerows: An international perspective on their origin, function and management. J. Environ Manage 60: 7-22.

Benke Sz., Madarász B., Bádonyi K., Kertész Á. 2010. A hagyományos és a talajkímélő müvelés madártani viszonyai, a szegélyterületek jelentösége a szántóföldi madarak elófordulásában. [Ornithological aspects of conventional and conservation tillage, significance of edges for the occurrence of farmland birds]. Tájökológiai Lapok 8, 3: 437-455. (In Hungarian).

Botta-Dukát Z. 2006. Két adventív Solidago faj növekedése különböző idöjárású években. [Growth of two adventive Solidago species in different years with different weather conditions]. In: 
Molnár E. (ed). Kutatás, oktatás, értékteremtés. A 80 éves Précsényi István köszöntése. [Research, education, value creation. The greeting of the 80-year-old Précsényi István]. Magyar Tudományos Akadémia Ökológiai és Botanikai Kutató Intézet, Vácrátót, pp. 45-51. (In Hungarian).

Bozó L. 2017. Kevermes madárvilága. [Birds of Kevermes]. Dél-békési Természetvédelmi és Madártani Egyesület, Kevermes. (In Hungarian).

Bozó L. 2018. Dél-Békés természeti értékei [Nature assets of South-Békés]. Dél-békési Természetvédelmi és Madártani Egyesület, Kevermes. (In Hungarian)

Bozó L. 2019. Migration and wintering of Fieldfare (Turdus pilaris) in southeastern Hungary. Ornis Hung. 27, 2: 86-99.

Bozó L., Bozóné Borbáth E., Tar L. 2017. Énekesmadarak öszi vonulása csatornaparti fasoron. [Songbird migration in a channel-sided alley]. Természetvédelmi Közlemények 23: 1-13. (In Hungarian).

Csörgő T., Karcza Zs., Halmos G., Magyar, G., Gyurácz, J., Szép, T., Bankovics, A., Schmidt, A., Schmidt, E. (eds). 2009. Magyar Madárvonulási Atlasz. [Hungarian Bird Migration Atlas]. Kossuth Kiadó Zrt., Budapest. (In Hungarian).

Csörgő, T., Kováts, L. 2009. Nagy fülemüle. [Thrush Nightingale]. In: Csörgő, T., Karcza Zs., Halmos G., Magyar G., Gyurácz J., Szép T., Bankovics A., Schmidt A., Schmidt E. (eds). Magyar Madárvonulási Atlasz. [Hungarian Bird Migration Atlas]. Kossuth Kiadó Zrt., Budapest, pp. 444-445. (In Hungarian).

Eversham B.C., Telfer M.G. 1994. Conservation value of roadside verges for stenotopic heathland Carabidae: corridors or refugia? Biodivers Conserv 3: 538-545.

Faaborg J., Holmes R.T., Anders A.D., Bildstein K.L., Dugger K.M., Gauthreaux S.A., Heglund P., Hobson K.A., Jahn A.E., Johnson D.H., Latta S.C., Levey D.J., Marra P.P., Merkord C.R., Nol E., Rothstein S.I., Sherry T.W., Sillett T.S., Thomson III F.R., Warnock N. 2010. Conserving migratory land birds in the New World: Do we know enough? Ecol. Appl. 20, 2: 398-418.

Forman R.T.T., Godron M. 1986. Landscape Ecology. John Wiley \& Sons, New York

Fülöp Gy., Szilvácsku Zs. 2000. Természetkímélő módszerek a mezőgazdaságban. [Nature-friendly methods in agriculture]. Magyar Madártani és Természetvédelmi Egyesület, Eger, pp. 19-44. (In Hungarian).

Gál J. 1968. A mezövédö erdösávok növényvédelmi vonatkozásai. [Plant protection aspects of shelter-belts]. Erdészeti Lapok 103: 450-476. (In Hungarian).

Gál J., Marosán M. 2003. A mezőgazdasági tevékenység által okozott kár a vadállományban. [Damage to wildlife caused by agricultural activity]. Növényvédelmi tanácsok: kertészet, növénytermesztés, szaktanácsadás 12: 36-37. (In Hungarian).

Gallé L., Margóczi K., Kovács É., Györffy GY., Körmöczi L., Németh L. 1995. River valleys: are they ecological corridors? Tiscia 29: 53-58.

Hadarics T., Zalai T. 2008. Magyarország madarainak névjegyzék. Nomenclator avium Hungariae. [An annonated list of the birds of Hungary]. Magyar Madártani és Természetvédelmi Egyesület, Budapest. (In Hungarian).

Herrmann G., Plakolm A. 1991. Ökologische Landbau. Österreichischer Agrarverlag, Wien

Karcza Zs. 2019. A Madárgyürüzési Központ 2018. évi beszámolója. [Annual report of the Hungarian Bird Ringing Center, 2018]. Magyar Madártani és Természetvédelmi Egyesület Madárgyürűzési Központ. (In Hungarian).

Kromp B. 1998. Wiener Windschutzhecken. Magistrat der Stadt Wien, Wien.

Legány A. 1991. A mezoovédő erdősávok és fasorok madártani szerepe és természetvédelmi jelentösége. [Significance of shelter-belts and rows of trees in respesct of ornithology and nature conservancy]. Aquila 98: 169-180.

Marton A., Csikós Cs. 2004. Mezövédö erdösávok és a fenntartható fejlödés. [Shelter-belts and the sustainable development]. Környezeti Tanácsok 4. Kiadja: KÖTHÁLÓ Környezeti Tanácsadó Irodák Hálózata, közreműködő: CSEMETE Természet-és Környezetvédelmi Egyesület, Szeged. (In Hungarian). 
R Development Core Team 2018. R: A language and environment for statistical computing. R Foundation for Statistical Computing. Vienna, Austria.

Svensson L. 1992. Identification guide to European passerines. Svensson, Stockholm.

Szarvas P. 2010. Mezövédö erdösávok, fasorok jellemzése, ökológiai feltárása, kihatásai. [Characterization, ecological exploration, and effects of shelter-belts and alleys]. PhD értekezés, Debrecen. (In Hungarian). 